\title{
ESTETIKA HINDU PADA PERWUJUDAN ORNAMEN CANDI DI JAWA
}

\author{
Riza Istanto \\ Universitas Negeri Semarang \\ E-mail: istantoriza@students.unnes.ac.id
}

\begin{abstract}
Abstrak
Indonesia memiliki beragam jenis seni bangun candi yang diperindah dengan adanya ornamen. Ornamen pada candi merupakan produk budaya yang syarat dengan nilai estetis dan religi kesenian Hindu. Tulisan ini membahas mengenai estetika Hindu pada perwujudan ornamen candi di Jawa, dengan pendekatan teori estetika Hindu sebagai pisau analisis. Hasil analisis menunjukkan bahwa perwujudan ornamen candi di Jawa memegang prinsip Sàmkhya-Yoga-Rasa, serta bakti. Pada visualisasi ornamennya tecermin pula nilai enam (sad) syarat atau perincian (angga) yaitu (1), (2) sadrsya, (3) pramana, (4) wanikabangga, (5) bhawa, dan (6) lawannya.
\end{abstract}

Kata kunci: candi, ornamen candi, estetika Hindu, dan candi Jawa Tengah

HINDU AESTHETICS IN THE REPRESENTATION OF TEMPLE ORNAMENTS IN JAVA

\begin{abstract}
Indonesia has various types of temple building art that are beautified with ornaments. The ornaments on the temple are cultural products that are rich in aesthetic and religious values of Hindu art. This paper article discusses Hindu aesthetics in the embodiment of temple ornaments in Java, with Hindu aesthetic theory as a knife of analysis . The results of the analysis show that the embodiment of temple ornaments in Java holds the principle of Sâmkhya-Yoga-Rasa, as well as bakti. The visualization of the ornament also reflects the value of six ( $\mathrm{sad})$ conditions or details (angga), namely (1) rupabheda, (2) sadrsya, (3) pramana, (4) wanikabangga, (5) bhawa, and (6) the opposite.
\end{abstract}

Keywords: temple, temple ornaments, Hindu aesthetics, and Central Java temple

\section{PENDAHULUAN}

Indonesia memiliki kekayaan budaya candi yang melimpah. Letak bangunan candi banyak tersebar di pulau Jawa, terutama Jawa Tengah dan Jawa Timur dengan aneka bentuk dan jenis.

Candi merupakan seni bangun peninggalan masa lampau (Indonesia Hindu-Budha) yang masih dapat dijumpai hingga saat ini. Sebagai produk budaya, bangunan candi diperindah dengan perwujudan ornamen pada dindingdinding bangunannya. Jenis ornamen candi bervariasi, berupa sosok manusia, hewan, tumbuhan, atau bentuk-bentuk lainnya yang menggambarkan aspek tertentu sesuai konsep bangunan yang dimaksud.

Menurut Syafii dan Rohidi (1987: 03), fungsi ornamen bagi masyarakat pada masa lampau (terutama masa prasejarah dan Hindu-Budha), adalah sebagai media untuk melampiaskan hasrat pengabdian, persembahan, penghormatan, dan kebaktian terhadap roh nenek moyang atau dewa yang dihormati, termasuk ornamen candi. Oleh karena itu, ornamen candi sebagai produk budaya yang berlatar agama Hindu-Budha, diciptakan tidak hanya memiliki nilai estetik melainkan juga nilai religius. 
Pemikiran mengenai nilai estetik seni pada setiap budaya memiliki karakteristik yang berbeda. Nilai estetik ini mengacu pada wacana yang otonom mengenai yang baik dan yang indah dalam kesenian. Nilai estetik suatu kesenian berkaitan pula dengan masyarakat pendukungnya. Termasuk budaya ornamen pada bangunan candi yang erat kaitannya dengan agama (Hindu-Budha). Tulisan ini akan menguraikan mengenai estetika ornamen candi di Jawa yang erat kaitannya dengan konsep estetika Hindu.

\section{PEMBAHASAN}

\section{Pengertian dan Fungsi Candi: Sebuah Pengantar Pembahasan}

Kata candi apabila dilihat dari asal katanya adalah candika. Perkataan tersebut berasal dari nama Durga sebagai dewi maut yaitu candika. Dewi Durga merupakan penguasa jiwa, dewi maut atau dewi kematian (Harto, 2005: 2). Kaitannya dengan Durga dan istilah cinandi inilah, akhirnya masyarakat menyebut candi sebagai makam.

Candi sebagai semacam pemakaman atau sebagai pemakaman hanya terdapat dalam agama Hindu. Hal tersebut karena, candicandi agama Budha dimaksudkan sebagai tempat pemujaan dewa belaka. Di dalamnya tidak terdapat peti pripih, dan arcanya tidak mewujudkan seorang raja. Abu jenazah dari para Biksu terkemuka ditanam di sekitar candi dalam bangunan stupa (Soekmono, 1973: 83).

Candi sesungguhnya bukanlah pemakaman. Anggapan ini sesungguhnya pembenaran oleh Soekmono (2005) melalui disertasinya menegaskan bahwa candi bukanlah makam, tetapi candi adalah bangunan kuil. Abu yang terdapat dalam pripih di dasar candi adalah abu binatang kurban, bukan abu manusia (raja). Terkait dengan anggapan ini, Harto (2005: 16) turut menjelaskan bahwa candi adalah salah satu bentuk perwujudan dharma agama bagi raja dalam konteks sistem religi Hindu sekaligus sebagai monumen peringatan meninggalnya raja atau kerabatnya.

Struktur bangunan candi secara fisik menggambarkan gunung Mahameru yang merupakan kayangan tempat tinggal para dewata (Jordaan, 2009: 63). Bangunan candi melambangkan alam semesta yang dikenal dengan konsep Triloka (Soekmono, 1973: 83-84). Konsep triloka ini pada candi terbagi menjadi tiga bagian. Kaki candi melambangkan bhurloka atau dunia tempat manusia berpijak, tubuh candi melambangkan bhuwarloka atau dunia tempat manusia telah mencapai kesucian atau kesempurnaan dan karenanya dapat berhadapan dengan dewa atau nenek moyang yang dipuja. Adapun atap candi melambangkan swarloka atau dunia para dewa dan roh nenek moyang.

\section{Ornamen Candi sebagai Produk Budaya}

Indonesia memiliki budaya candi yang tidak terhitung jumlahnya, tersebar di seluruh daerah di pulau Jawa dan Bali, dan sebagian besar terletak di Pulau Jawa, terutama Jawa Tengah dan Jawa Timur. Bentuk candi sangat beragam dan bervariasi. Mulai dari peninggalan masa Mataram kuno (abad 9-10 M) contohnya candi-candi dataran tinggi Dieng, candi Gedongsanga, candi Borobudur, hingga candi Prambanan. Peninggalan masa Kediri (abad 11-12 M) contohnya candi Jalatunda, candi Panataran, hingga Goa Selomanggleng. Peninggalan masa Singasari (abad 12-14 M) contohnya candi Jago, candi Jawi, candi Kidal. Serta peninggalan masa Majapahit (abad 13-15 M) mulai dari candi-candi Trowulan hingga candi Mirigambar (lihat Harto, 1999; Munandar, 2015).

Agama Hindu dan Budha berkembang di Indonesia antara abad VII-XV Masehi, dan kebudayaan materi yang ditinggalkan adalah tempat-tempat suci yaitu candi, stupa, goa pertapaan, dan kolam suci (patirthan) (Santiko, 1995: 02). Seringkali bangunan-bangunan tersebut diperindah dengan adanya ornamen, teristimewa pada bangunan candi.

Menurut Gustami (1980: 04), ornamen merupakan komponen produk seni yang ditambahkan atau sengaja dibuat untuk tujuan hiasan. Secara umum, ornamen memiliki fungsi yang dapat dipilah ke dalam tiga jenis, yaitu fungsi murni estetis, fungsi simbolis, dan fungsi konstruktif (Sunaryo, 2009: 04). 
Keberadaan ormanenpada candi, berfungsi sebagai pengisi kekosongan suatu bidang atau dinding candi. Ornamen pada candi juga memiliki fungsi sebagai media untuk melampiaskan hasrat pengabdian, persembahan, penghormatan, dan kebaktian terhadap nenek moyang atau dewa yang dihormati (Syafii dan Rohidi, 1987: 03). Karena itu, ornamen candi sebagai produk budaya yang berlatar agama Hindu-Budha, diciptakan tidak hanya bernilai estetik melainkan juga bernilai religius.

Berbicara mengenai ornamen pada candi erat, maka erat kaitannya dengan relief. Hal ini tersirat pada pernyataan Holt (2000: 40) yang menyampaikan bahwa dinding candi "dihiasi" dengan relief-relief naratif dan dekoratif. Lebih lanjut, berdasarkan fungsinya, Jordaan (2009: 121-154) menggolongkan relief pada candi menjadi relief dekoratif, relief naratif, dan relief ikonik. Relief naratif merupakan reliefrelief yang memuat cerita tertentu, sementara relief-relief dekoratif merupakan relief yang diterapkan sebagai hiasan atau ornamen pada candi, adapun relief ikonik merupakan relief yang menggambarkan tokoh dewa atau tokohtokoh penting lainnya yang terkait dengan penggambaran sebuah candi (Jordaan, 2009: 121).

\section{Estetika dalam Pandangan Hindu}

Kesenian apapun bentuknya, pada dasarnya merupakan hasil kreativitas manusia atau seniman yang menciptakan. Sebagai hasil olah rasa, cipta, dan karsa seniman, kesenian tidak bisa lepas dari ikatan-ikatan nilai luhur budaya. Termasuk pula estetika yang hidup dan berkembang di lingkungan masyarakat tempat asal seni yang bersangkutan karena, karya seni merupakan ekspresi keindahan masyarakat yang bersifat kolektif (Sunarto, 2018). Estetika merupakan cabang filsafat yang menelaah dan membahas tentang seni dan keindahan serta
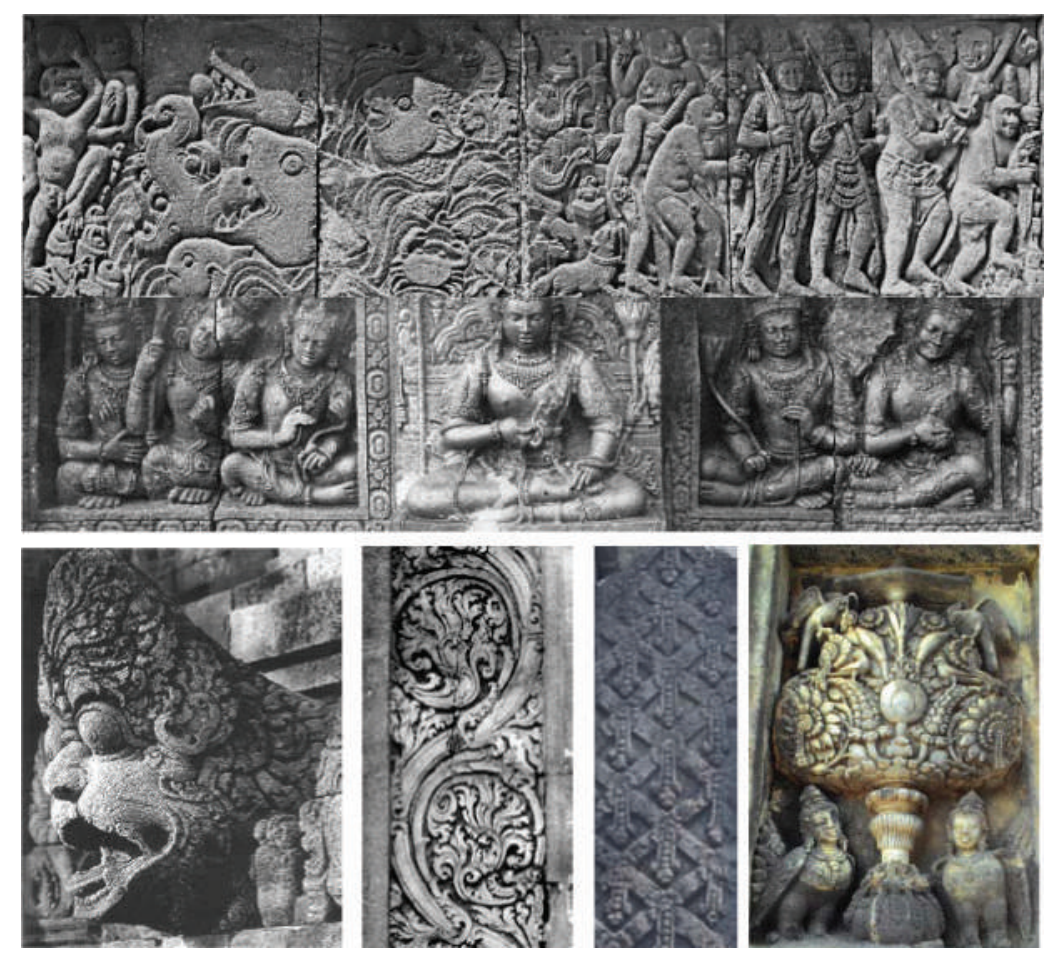

Gambar 1. Visualisasi ornamen pada candi. Relief naratif Ramayana di candi Prambanan (atas), Relief ikonik dewa penjaga arah mata angin (tengah), dan Relief dekoratif secara urut dari kiri ke kanan motif kedok, motif sulur, motif geometris, dan motif kalpataru dengan hewan pengapit

Kinara-Kinari (bawah).

Sumber: Sunaryo, 2009 dan dokumen penulis 
tanggapan manusia terhadapnya (Suharso dan Retnoningsih, 2014: 136).

Junaedi (2016: 07) menjelaskan bahwa estetika tidak hanya membahas tentang persoalan karya seni melainkan juga meliputi ranah yang lebih luas yaitu subjek estetis, objek estetis, hingga nilai estetis. Objek estetis merupakan aspek yang diamati maupun diciptakan seseorang, subjek estetis merupakan pengamat atau kreator yang membuat objek estetis, sedangkan nilai estetis ialah tolak ukur subjek untuk menimbang keindahan atau kejelekan maupun ketertarikan atau ketidaktertarikan pada suatu objek. Lebih lanjut Sunarto (2018: 16) menjelaskan estetika tidak hanya berkaitan dengan sifat dan nilai seni tetapi juga dengan tanggapan-tanggapan terhadap benda-benda alam yang menemukan ekspresi dalam bahasa yang indah (beautiful) dan yang jelek (ugly).

Candi (terkusus ornamen pada bahasan ini) merupakan hasil kreativitas seniman. Sangat sarat akan muatan estetis yang dijiwai oleh nilai-nilai budaya yang diikat oleh agama Hindu. Dalam estetika Hindu dikenal rumusan bahwa suatu hasil seni untuk bisa dikatakan indah dan berhasil harus memenuhi enam (sad) syarat atau perincian (angga), karena itu rumusannya disebut sad-angga.

Enam syarat pegangan tersebut adalah (1) rupabheda, artinya pembedaan bentuk, maksudnya bentuk-bentuk yang digambarkan harus dapat segera dikenali oleh yang melihatnya, harus dapat dikenali karakteristiknya yang berbeda antara satu dengan lainnya; (2) sadrsya, artinya kesamaan dalam penglihatan, maksudnya bentuk-bentuk yang digambarkan harus sesuai dengan ide yang dikandung di dalamnya; (3) pramana, artinya sesuai dengan ukuran yang tepat. Di samping berhubungan dengan ukuran, prinsip pramana juga menuntut dipakainya pola-pola bentuk yang tepat dalam penggambaran, dalam hal ini menggunakan pola-pola bentuk yang sudah ditetapkan; (4) wanikabangga yaitu penguraian dan pembikinan warna. Berhubungan dengan perihal lambang-lambang warna; (5) bhawa yaitu dapat diartikan sebagai suasana dan sekaligus pancaran rasa; dan (6) lawanya berarti keindahan daya pesona, wibawa atau greget. Seni bukan hanya soal teknik atau keterampilan, tetapi ekspresi yang memberikan wibawa transendental. Dengan kehadiran lawanya, suatu hasil seni akan menimbulkan kesan yang dalam pada penikmat, bahkan bisa mempengaruhi batinnya (lihat Wirjosuparto, 1956: 08-10; Sumardjo 2000:337).

Selain itu, terkait pula dengan acuan etos kerja kreatif Hinduisme. Ideologinya diturunkan dari eksistensi Tuhan yaitu SatyamÚiwam-Sundharam (Kebenaran-KebajikanKeindahan) kedalam Sàmkhya-Yoga-Rasa (Yasa, 2010: 160). Sàmkhya adalah ajaran filsafat dualis dikotomis yang tersusun atas purû̂a (azas roh, energi) dengan prakåti (azas materi). Kaitannya dengan yoga, sàmkhya adalah landasan teoretis, yaitu peta spiritual yang memberi petunjuk tentang dasar, arah, dan tujuan yoga dipraktikkan.

Yoga bagi seniman merupakan jalan yang dilalui dalam upaya menyatukan diri dengan benda ciptaannya. Sebelum menciptakan sesuatu, seorang seniman harus menciptakan dahulu benda tersebut dalam pikirannya, dengan jalan memusatkan segala pikirannya kepada benda yang diciptakan tersebut, pencipta karya seni (seniman) mematikan segala perhatian lainnya dan dengan jalan yoga bersatu dengan Tuhan (Wirjosuparto, 1956: 07). Sedangkan rasa lebih bersangkut dengan hal yang menyenangkan dan membahagiakan, yaitu keindahan yang dalam khazanah Hindu disebut sundharam (Yasa, 2010: 160). Selain itu, prinsip bakti bagian yang penting pula dalam penciptaan karya seni. Prinsip ini merupakan prinsip rasa cinta kasih dan menyerah kepada dewa yang melandasi kegiatan kesenian seniman. Seperti misalnya dalam membangun kuil untuk dewa (rumah dewa) (Harto, 1999: 40).

\section{Estetika Hindu dalam Perwujudan Ornamen Candi}

Mengenai ketentuan relief atau ornamen pada candi, Bosch (dalam Santiko 1995: 7) menyebutkan bahwa dalam kitab Manasara 
(salah satu kitab tentang arsitektur) tidak ada ketentuan tentang jenis relief apa yang seharusnya dipahatkan pada dinding bangunan suci, hanya disebutkan bahwa kuil dapat diberi hiasan agar terlihat indah. Akan tetapi, apa yang diwujudkan sebagai ragam hias candi tetap berkaitan dengan simbol-simbol yang mewakili gambaran Gunung Buana (Meru atau Kailasa), agar dewa sudi singgah pada bangunan tersebut (simak Leeuw dalam Jordaan, 2009: 151).

Jenis relief yang menghiasi dindingdinding candi secara umum menurut Jordan (2009: 121-154) adalah relief ikonik, relief dekoratif, dan relief naratif yang beragam jenis serta bentuk perwujudannya. Dilihat dari relief naratifnya saja, keragaman kisah atau cerita yang tersaji dalam relief antara lain yaitu relief kisah Ramayana, Krisnayana, Garudeya, Mahabarata, Sudamala, Syaimbara, Drupadi, Sri Tanjung, Kunjara Karna, dan lain sebagainya yang diambil dari teks-teks agama Hindu atau cerita yang berkembang pada masyarakat setempat. Hal ini sesuai dengan pendapat sari (2008: 78) bahwa isi karya-karya seni rupa Hindu/Budha sering didasarkan pada teks-teks keagamaan dan mitologi.

Relief-relief dekoratif diterapkan sebagai hiasan atau ornamen candi. Relief yang tergolong dalam jenis ini diantaranya motif kala, makara, manusia dan binatang, sulursuluran, tekstil dan pola-pola geometris, serta jenis lainnya. Pada bangunan candi terdapat ragam hias sulur-sulur daun yang melingkarlingkar merupakan penggambaran hutan belukar dan semak-semak lebat di gunung Mahameru, bunga-bunga padma (teratai) dan tanaman menjalar lain merupakan simbol danau dan kolam di lereng gunung tersebut, kepala Kala penghias ambang pintu merupakan merupakan mahluk supernatural penjaga kesucian Mahameru, relung-relung merupakan simbol goa-goa di lereng gunung pertapaan kaum agamawan yang telah mengalahkan nafsu duniawi, dan antefix-antefix (simbar) yang berderet di tingkatan atap merupakan simbol perbukitan di sekitar puncak utama Mahameru (Munandar, 2015: 158-159). Sedangkan relief ikonik merupakan relief yang menggambarkan tokoh dewa atau tokoh-tokoh penting lainnya yang terkait dengan penggambaran sebuah candi, contohnya relief-relief para penjaga mata angin (astadikpala), relief para pemain musik, Kinara-kinari dan lain sebagainya (Jordaan, 2009: 121; Istanto \& Syafii, 2017).

Meskipun penciptaan candi termasuk ragam ornamen yang melekat didinding candi banyak mendapat pengaruh dari kesenian India, keberadaan unsur lokal yang membedakan dengan budaya India masih terlihat di sanasini. Hal tersebut merupakan kemampuan kreatif para seniman atau pemahat candi dalam mengolah budaya asing (India) dengan unsur lokal (lihat Soekmono, 2005; Santiko, 1995; Sedyawati dalam Fontein, 1990: 97-100).

Penciptaan candi maupun relief melibatkan banyak orang, masing-masing pemahat dalam mencipta satu jenis ornamen berbeda bentuknya. Ini merupakan kreativitas seniman pemahat candi yang erat kaitannya dengan faktor yoga.

Meskipun yang diciptakan adalah jenis yang sama, namun para pemahat candi seringkali berbeda dalam mewujudkannya. Dalam kasus ornamen motif Prambanan yang berjumlah 270, Istanto \& Syafii (2017) mencermati adanya perbedaan di sana sini dalam menggambarkan ornamen tersebut. Ornamen tersebut dibuat oleh beberapa orang. Sehingga, meskipun memiliki tema sama, para pemahat memiliki persepsi masing-masing berkenaan dengan aspek yoga tersebut.

Yoga bagi seniman merupakan jalan yang dilalui dalam upaya menyatukan diri dengan benda ciptaannya. Sebelum menciptakan sesuatu, seorang seniman harus menciptakan dahulu benda tersebut dalam pikirannya, dengan jalan memusatkan segala pikirannya kepada benda yang diciptakan tersebut, pencipta karya seni (seniman) mematikan segala perhatian lainnya dan dengan jalan yoga bersatu dengan Tuhan (Wirjosuparto, 1956: 07). Sebelum mencipta ornamen candi, para pemahat melakukan yoga menyatukan diri dengan apa yang akan dibuat. Oleh karena itu, pada setiap candi perwujudan ornamen sering kali bervariasi (tidak sama antara candi satu 
dengan lainnya). Misalnya ornamen kala di Candi Kalasan akan berbeda dengan ornamen kala yang ada di Candi Sewu ataupun di Candi Prambanan, meskipun candi-candi tersebut letaknya berdekatan.

Penciptaan candi merupakan wujud kebaktian masyarakat Hindu yang diperuntukkan kepada dewa, terutama ornamen-ornamen yang melingkupinya. Perwujudan ornamen menggambarkan dewa yang dipuja dan tempat tinggal para dewa (Leeuw dalam Jordaan, 2009), sehingga syarat akan nilainilai religius. Tidak hanya itu, ungkapannya juga divisualisasikan secara indah dan penuh pertimbangan. Kesemuanya ini merupakan representasi dari prinsip Sàmkhya-Yoga-Rasa yang dipegang para seniman candi di Jawa.

Selain prinsip di atas, enam syarat pegangan dalam penciptaan seni, terlihat pada perwujudan ornamen candi. Prinsip sad angga (enam rincian) tersebut yaitu (1) rupabheda, (2) sadrsya, (3) pramana, (4) wanikabangga, (5) bhawa, dan (6) lawanya.

Prinsip pertama yaitu prinsip rupabedha. Prinsipiniberperandalammewujudkanornamen candi yang mudah dikenali karakteristiknya, berbeda antara ornamen satu dengan lainnya. Ornamen-ornamen yang divisualisasikan pada dinding candi memiliki ciri ikonografi yang dapat dikenali perbentukannya (Munandar, 2018: 45-53; Istanto \& Syafii, 2017). Prinsip yang kedua merupakan sadrsya. Prinsip ini memiliki artinya bahwa, perwujudan ornamen candi memiliki kesamaan dalam penglihatan. Bentuk-bentuk ornamen yang digambarkan pada candi sesuai dengan ide yang dikandung di dalamnya. Misalnya Kinara-Kinari pada candi-candi di Jawa Tengah. Penggambaran Kinara-Kinari (pemahaman Hindu) menyerupai burung namun berkepala manusia.menurut Bernet-Kempres (Ratnawati, 1989: 339-340) merupakan pemain musik kayangan laki-laki dan perempuan.

Prinsip yang ketiga merupakan sadrsya. Prinsip ini berkaitan dengan proporsi. Penggambaran ornamen candi mempertimbangkan proporsi yang tepat, sehingga mudah dikenali penggambaran suatu tokoh atau motif hias tertentu. Prinsip ini juga dipegang dalam menggambarkan motif dari tokohtokoh mitologis yang pada dasarnya adalah perwujudan dari ide-ide tertentu seperti Kinara-Kinari, hare, garuda, ganna, dan motif lainnya di candi Prambanan (Istanto \& Syafii, 2017); misalnya pula relief-relief para penjaga mata angin (astadikpala) di candi Siwa (Jordaan, 2009: 121). Prinsip keempat adalah wanikabangga yang berhubungan dengan perihal lambang-lambang warna. Contohnya penggambaran wujud bunga teratai. Bunga teratai dilambangkan dengan tiga warna yaitu teratai putih merupakan bunga mekar ( $p a d m a)$, teratai biru merupakan setengah mekar (utpala), dan teratai putih merupakan bunga kuncup (kumuda) (Sunaryo, 2009: 154).

Adapun prinsip yang kelima adalah bhawa yang berarti suasana atau pancaran rasa dan prinsip keenam adalah lawanya yang berarti keindahan daya pesona. Perwujudan ornamen candi dibuat sedemikian rupa menggambarkan kedekatan dengan gunung Meru (tempat para dewa) dengan kecermatan teknik yang tinggi dan komposisi penyusunan yang memberi kesan estetis. Hal ini menunjukkan pengamalan prinsip bhawa (pesona) dan lawanya (keindahan).

\section{KESIMPULAN}

Ornamen pada candi merupakan produk budaya yang syarat dengan nilai estetis dan religi kesenian Hindu. Perwujudan ornamen candi terkandung enam (sad) syarat atau perincian (angga) yaitu (1) rupabheda, (2) sadrsya, (3) pramana, (4) wanikabangga, (5) bhawa, dan (6) lawanya. Terdapat juga prinsip Sàmkhya-Yoga-Rasa, serta bakti yang semuanya ini tercermin dalam perwujudan ornamen-ornamen candi di Jawa.

\section{DAFTAR PUSTAKA}

Fontein, Jan, dkk. 1990. The Sclupture of Indonesia. Washington: National Gallery of Art.

Gustami. 1980. Nukilan Seni Ornamen. Yogyakarta: STSRI-ASRI. 
Harto, D.B. 1999. "Relief Candi Tigowangi dan Candi Surawana: Tinjauan Cara Wimba dan Tata Ungkapannya". Tesis. Bandung: Magister Seni Rupa dan Desain ITB (Tidak Dipublikasikan)

Harto, D.B. 2005. "Tata Cara Pendirian Candi: Perspektif Negarakartagama". Dalam Jurnal Seni Imajinasi, Volume 3 Juli 2005. Semarang: FBS Unnes. Hlm. 1-18.

Holt, Clair. 2000. Melacak JejakPerkembangan Seni di Indonesia. Bandung: ati.line

Istanto, Riza\& Syafii. 2017. "Ragam Hias Pohon Hayat Prambanan". Dalam Jurnal Seni Imajinasi, Volume XI No. 1 Januari 2017. Semarang: Fakultas Bahasa dan Seni Unnes. Hlm. 19-28

Jordaan, Roy (ed.). 2009. Memuji Prambanan. Jakarta: Yayasan Obor Indonesia

Munandar, Agus A. 2015. Keistimewaan Candi-Candi Zaman Majapahit. Jakarta: Wedatama Widya Sastra

Munandar, Agus A. 2018. Sntarala Arkeologi Hindhu-Budha. Jakarta: Wedatama Widya Sastra

Santiko, Hariani. 1995. "Seni Bangun Sakral Masa Hidu-Budha di Indonesia (Abad VIII-XV Masehi): Analisis Arsitektur dan Makna Simbolik". Dalam Pidato, Disampaikan pada Upacara Pengukuan sebagai Guru Besar Madya Tetap pada Fakultas Sastra UI 1995. Depok: Fakultas Sastra UI

Sari, Sriti Mayang dan Raymond Soelistio Pramono. "Kajian Ikonografis Ornamen pada Interior Klenteng Sanggar Agung Surabaya”. Dalam Jurnal Seni Dimensi Interior, Volume 6 No. 2 Desember 2008. Surabaya: Fakultas Seni dan Desain Universitas Kristen Petran. Hlm. 73-84
Soekmono, R. 1973. Pengantar Sejarah Kebudayaan Indonesia Jilid 2. Yogyakarta: Kansius

Soekmono, R. 2005. Candi: Fungsi dan Pengertiannya. Tanpa Kota: Jendela Pustaka

Sumardjo, Joko. 2000. Filsafat Seni. Bandung: ITB

Sunarto. 2018. Estetika Filosofis. Yogyakarta: Lontar Media

Sunarto. 2018 dalam Pengantar Penyunting Buku: Hospers, John. 2018. Filsafat Estetika. Diterjemahkan oleh Jalaludin Rumi.Yogyakarta: Tafa Media

Sunaryo, Aryo. 2009. Ornamen Nusantara: Kajan Khusus tentang Ornamen Indonesia. Semarang: Dahara Prize

Sunaryo, Aryo., dkk. 2009. "Bentuk dan Pola Ornamen pada Candi Kalasan dan Prambanan". Laporan Penelitian. Semarang: FBS Unnes (Tidak Dipublikasikan)

Syafii, dan Rohidi, T.R. 1987. Ornamen Ukir. Semarang: IKIP Semarang Press.

Wirjosuparto, Sutjipto. 1956. Sedjarah Seni Artja India. Jakarta: Kalimosodo

Yasa, I Wayan S. 2010. "Estetika Hindu : Rasa sebagai Taksu Seni Sastra". Dalam Jurnal Mudra, Volume 25, No. 2 September 2010. Bali: ISI Bali. Hlm. 159-171 